\title{
Article
}

\section{Exercising Genres: A Rejoinder to Anne Freadman}

Carolyn R. Miller

North Carolina State University

Anne Freadman's engagement with Rhetorical Genre Studies (RGS) is informed, generous, illuminating, and provocative. She does us the service of placing into a broad intellectual context the recent conversations about genre within the developing RGS tradition. She has done me the honour of reading my work thoroughly and carefully, more carefully in some cases than I wrote it. She has taken up Rhetorical Genre Studies in her own way and given us much in return. And in response, I feel ... well ... compelled to reply, to take up the conversation, to add to the chain of semiosis.

Why? What is the nature of such compulsion? How can I feel compelled-or impelled—to respond even before I quite know what I am going to say? For me, Freadman's essay presents an exigence: it "strongly invites utterance," in Lloyd Bitzer's (1968) words (p. 5). There are both psychological and sociological dimensions of my impulse to reply, and both situation-specific and historical-institutional aspects. All of which may very well go to prove Anne Freadman right. And yet I reply not (just) to say how right she is. That does not require my saying so. In taking up her reflections in both generic and specific ways (necessarily), I demonstrate her point that genre is interactional. The bits of ceremony here adumbrate the generic place I inhabit (the journal's imprint, the medium and technological platform, the title, and so on), yet it is the specific response that must reveal the precise nature of the generic gesture(s) that I hope will be taken up in turn, by Anne and by others, all in their own ways.

The first genre I must call upon is that of self-defense, the apologia, with a dose of clarificationbecause Freadman undoes a point I had considered central, i.e., that exigence is the core of rhetorical situation, and recurrent exigence the core of genre (Miller, 1984, p. 157). She asks: "Is exigence definitional of the genre, as Miller requires, or does it describe the occasion of its use? Is it consolidated by its recurrence, or is it changed in its very occurrence?" (Freadman, 2020, p. 120). Indeed, I have 
seen exigence as central to rhetorical action, and recurrent exigence as central to a rhetorical understanding of genre and "definitional" of genres. I've also used other terms to gloss the work I've asked exigence to do: motive (Miller, 1984) and function (Miller, 2012, 2015) most prominently, and intention and purpose by contrast (Miller, 1984, 2015).

Have I been imprecise in my use of terms? Undoubtedly. Genre is an imprecise business. I want to argue that there can be advantages to certain kinds of imprecision, because social interactions are inexhaustibly complex. Nevertheless, when I invoke the genre of apologia in this context (in these pages), you understand what I want to be doing. The invocation makes you recognize or detect something in the situation presented by Freadman's essay, something that is familiar, a precedent, something that is indeed recurrent; and beyond this, it helps you understand my motivation, the exigence as I have construed it for you, the action I am aiming at. (And my overt invocation aims to guide your construal of what is going on, in both generic and specific terms.) I want you to recognize that I feel impelled by a sense of collegial responsiveness but also by a feeling of proprietary obligation and of intellectual challenge, to justify the positions I took in 1984-and perhaps to demonstrate how my thinking has improved since then. These are motives, insofar as I can be aware of and honest about them. And they are motives that all those reading this can likely recognize both in me and in themselves. They impel my particular rhetorical action in this particular situation, but they also shape and constrain that action and make it intelligible and interpretable.

Exigence is an externalization of motive, an intersubjective recognition, or what I have called an "objectified" social motive. It takes rhetorical action out of the realm of individual psychology and into the social arena. Without motive, no action; without exigence, no socially recognizable action. This is why I want to say that exigence must be intrinsic to a rhetorical understanding of genre, that is, to an understanding that centres on language in use.

Freadman (2020) writes that "if exigence were intrinsic to a genre, we would have to accept that genres are locked into specifiable contexts" (p. 120); however, she objects, because genres can be recontextualized and they thus have changing use-values, or functions, we can't accept this. Indeed, genres can be recontextualized, as well as embedded, mixed, hybridized, and reformulated. But if our understanding of context, or situation, allows for recurrence, for typification, then the specification of context will be at a level of generality that unlocks-not all possible contexts but those that are socially recognizable as related-enough to count as recurrence. And if context-and with it function-differ sufficiently from earlier uses, then we might agree that we're working with a new genre. A recontextualization turns a genre into a gesture, a rhetorical "move," perhaps, that alludes to the 
motives, forms, and constraints of that genre, but the recontextualization occurs in its own rhetorical situation, which it also modifies and enriches (or complicates).

I am reminded of Kenneth Burke's (1965) insight that "motives are shorthand terms for situations" (p. 29), that "differences in our ways of sizing up an objective situation are expressed subjectively as differences in our assignment of motive" (p. 35), and that "we discern situational patterns by means of the particular vocabulary of the cultural group into which we are born" (p. 35). Insofar as motives are such cultural patterns and not idiosyncratic urges or private intentions, they become exigences. And insofar as these patterns are worth identifying as cultural categories-insofar as they give form and meaning to our collective life-they become recurrent exigences, or, in Schutz's (1973) terms, they become typified. As I noted in 1984, "it is through the process of typification that we create recurrence" (p. 157), and right now I want to emphasize the word "create." Similarly, to revert to another idea that motivated me in 1984, Michael Halliday's (1978) notion of the situation type makes of it "not an inventory of ongoing sights and sounds but a semiotic structure" that is "variable in generality, ... covering a greater or smaller number of possible instances" (Halliday, 1978, pp. 122, 114). The situation type, or recurrent rhetorical situation, bears a relationship to specifiable contexts but is not "locked" into them.

To come at this from a slightly different angle, Freadman (2020) asks "why the genre is distinct from the situation in which it takes place" (p. 127); indeed, Halliday's view of situation as a semiotic structure and my own view that situations are matters of social definition lead us in this same direction: we should not be looking for discourse and its container, for a bright line between text and context. But I want to add that what makes a situation a rhetorical situation is seeing it as having, or including, an exigence. Freadman proposes to replace exigence with jurisdiction and ceremony, the first to capture the function of a genre and the second to capture its manifestation in a situated occasion. And indeed, both of these are aspects of the way a genre becomes instantiated and both are implied by exigence, but to my mind, they miss the mark. Function and situatedness are both inextricable aspects of genre. A eulogy can be spoken in a church, in an office, on a gang-controlled street corner (I have been watching "The Wire"), if a relevant exigence can be recognized or invoked, and if a relevant audience is present or invokable. Although these situated occasions might be quite different, if the rhetorical event is recognized as serving the function of a eulogy, then there must be something generically similar about the occasions, ceremonials aside. But the differences of occasion may also lead to differences of function and thus to differentiation of genre.

It's true that both motive and exigence invite us to look for origins-as Freadman (2020) has it, 
toward something that "precedes the 'emergence and survival' of the genre" (p. 123), making exigence "intrinsic" (p. 123) and therefore enduring and constraining, so as to "preclude" change (p. 129). But as a more-or-less elastic social recognition that is itself a typification over a variety of prior experiences, a recurrent exigence admits incremental change, both as motivation and as uptake, always conditioned by institutional, technological, and cultural change. In fact, the dynamic discursive environment of the Internet provides ample illustration of such change; in my studies of blogging with Dawn Shepherd, we argued two points that are relevant here. First, that the exigence for blogging and the practices of blogging co-evolved, making it difficult to say which came first; and second, that new genres or subgenres of blogging emerged rapidly from early blogging experience-that is, bloggers and their audiences recognized distinctively different uses as categories of practice deserving recognition (Miller \& Shepherd, 2004, 2009). And as I have argued elsewhere, "in genre we are seeking not the stabilization of [practices and performances] but rather the stabilization of shared recognitions and social agreements, as represented by naming, replication, and metacommentary" (Miller, 2017, p. 5).

So I would want to say, contra Freadman, both that exigence is definitional of the genre and at the same time that it describes the occasion of its use; both that exigence is consolidated by its recurrence (i.e., it is typified) and that it is changed in its very occurrence, since recurrence is never (can never be) precise replication, and change is never untethered from a history. If this is an ambiguity between the genre in actu and the genre in virtu, it is a useful and productive ambiguity that gets at the heart of what it is that genre does for us both conceptually and practically: it connects.

Let me cite ${ }^{1}$ another genre now: the admiring thank-you note, for Freadman's work in disentangling agent from subject. Rhetoric does indeed need the agent, particularly a rhetoric that has motive and exigence as central notions. Freadman (2020) chooses to leave aside the complications and ambiguities of the "interior states and personal qualities" (p. 118) implicated in "subjectivity," seeing them as unhelpful "if genre is to be taken as a fully rhetorical way of thinking about discourse" (p. 118). Freadman's "fully rhetorical” approach focuses on the skill of the rhetor, as "trained, learned, and performed" (p. 118) and available to consciousness as meta-understanding. Yet, I wonder whether this focus makes of rhetoric an exclusively productive art and short-changes its capacities as an interpretive art. In the interpretation and criticism of rhetorical practice, I suggest that we do need to recognize the subject, to give the agent an unconscious, and to re-admit the workings of

\footnotetext{
${ }^{1}$ To use Derrida's (1980) term.
} 
power on the subject. Any rhetorical performance must be the result of more than deliberate rhetorical skill (as I struggle here with all that escapes my own understanding and control). Insofar as genres represent the persistence of tradition, its saturation of our life-world(s), we are indeed subject to them: we learn from them, (as we) re-shape ourselves to them, and (as we) resist and adapt them. Genres help shape us as subjects, and as agents we test ourselves and our strategies with and against genres.

Yet another genre I must invoke here is retraction. Freadman points out the difficulties inhering in the term system, a term I have not used carefully. She draws our attention particularly to the importance of diachronic relationships and the consequent difficulties of synchronic, systemic relationships among genres. "Any genre, then, alludes to, or carries, the history of its own practice, and rhetoric is always a study of practice" (Freadman, 2012, p. 547), she has said, and practice is so local, so contingent, so strategically undetermined that it cannot be contained or described by a system. I might once have thought it possible, or at least desirable, to fulfill a structuralist ambition of describing “a 'system of genres' presupposing a 'system of exigences'” (Freadman, 2020, p. 122). Such a system might have made possible a classification of said genres, another term I have used carelessly. But if I have learned anything about genres in the past few decades it is that cultural categories such as these are not systematic or systematizable; not only do they change over time and with usage but even in any instant they do not form any coherent structure because they arise in situations that are themselves in flux, within communities that overlap, and from histories that differ. ${ }^{2}$ This is particularly true with what I have called "vernacular genres," such as those created by voluntary communities of use in internet environments, but it is also largely true in more regulated environments such as corporations, schools, and other institutions (Miller, 2017), which also have their complex histories, interests, and shifting loci of power.

Nevertheless, we do need some term to describe synchronic relations among genres, or what Freadman (2020) admits as "local and provisional systems" (p. 122). Several terms have been in use in addition to genre system: genre sets, to describe the group of interacting genres used by a class of professionals (such as tax accountants) to accomplish their work (Devitt, 1991); genre repertoire, to describe the collection of genres "that are routinely enacted by members of [a] community" (in this

\footnotetext{
${ }^{2}$ It's worth noting the similarities to the organic world: biological organisms are much more difficult to systematize, taxonomize, and classify than nineteenth-century biologists had hoped. The term species describes a phenomenon so dynamic that some hold it to be useless; and there are multiple and conflicting schools of thought about whether taxonomy and classification can have a principled basis or whether they must be a matter of practical convenience only (Dennett, 1995, p. 95; Mayr, 1982, p. 251).
} 
case an inter-organizational working group of computer programmers) (Orlikowski \& Yates, 1994, p. 542); and genre ecology, to describe "how genres jointly mediate work," or in other words how genres connect workers to each other and to different stages and aspects of their work (Spinuzzi, 2002). Freadman (2020) herself at one point uses economy of genres (p. 124). I express no preference here, only an appreciation for the terminological difficulty.

And yet more terminological difficulties: what to call the "social sphere that regulates discourse" (Freadman, 2020, p. 122)? Bakhtin uses "spheres of activity" (Bakhtin, 1986, p. 60 and passim). I have used domains and communities of use (Miller, 2017). Freadman (2020) uses jurisdiction here again (p. 124), the term she also uses in place of exigence-as-function, revealing how closely she ties function to the regulating social sphere. I prefer to distinguish these because, as I noted above, a rhetorical exigence can be recognizable in more than one social sphere, and a given social sphere or community can sustain multiple exigences.

I have invoked several genres here, and yet what I have produced is none of these. In explicitly invoking multiple genres, I illustrate the point that genres may be recontextualized, embedded, combined. The genres of the apologia, the thank-you, and the retraction-not as forms but as actions, gestures-serve here as what John Swales (2004) has called "moves," that is, "discoursal or rhetorical unit[s] that perform a coherent communicative function in a written or spoken discourse"; moves are "functional, not ... formal," and thus can be a clause, a sentence cluster, or a paragraph (or more) (pp. 228-229). The moves I make are available, but not obligatory, constituents or aspects of the ostensible genre of the academic response, which is framed here by the immediate occasion of Freadman's "Tardy Uptake," by the medium afforded by this journal, by the academic audience I have learned to imagine, and by the traditions and conventions of academic exchange. That is the spirit in which I offer my response, and what would make me, and it, happy, ${ }^{3}$ is to have it taken up in that same spirit.

\section{References}

Austin, J. L. (1975). How to do things with words (2nd ed.). Cambridge, MA: Harvard University Press.

\footnotetext{
3 In Austin's (1975) sense.
} 
Volume 30, 2020

http://journals.sfu.ca/cjsdw

Bakhtin, M. M. (1986). The problem of speech genres (V. W. McGee, Trans.). In C. Emerson \& M. Holquist (Eds.), Speech genres and other late essays (pp. 60-102). Austin: University of Texas Press.

Bitzer, L. F. (1968). The rhetorical situation. Philosophy and Rhetoric, 1, 1-14.

Burke, K. (1965). Permanence and change: An anatomy of purpose (Reprint ed.). Indianapolis, IN: Bobbs-Merrill.

Dennett, D. C. (1995). Darwin's dangerous idea: Evolution and the meanings of life. New York, NY: Simon \& Schuster.

Derrida, J. (1980). The law of genre (A. Ronell, Trans.). Critical Inquiry, 7(1), 55-81.

Devitt, A. J. (1991). Intertextuality in tax accounting: Generic, referential, and functional. In C. Bazerman \& J. Paradis (Eds.), Textual dynamics of the professions: Historical and contemporary studies of writing in professional communities (pp. 336-355). Madison: University of Wisconsin Press. Retrieved from https://wac.colostate.edu/docs/books/textual_dynamics/chapter14.pdf

Freadman, A. (2012). The traps and trappings of genre theory. Applied Linguistics, 33(5), 544-563. doi:10.1093/applin/ams050

Freadman, A. (2020). A tardy uptake. Canadian Journal for Studies in Discourse and Writing/Rédactologie, 30, 105-132. doi: 10.31468/cjsdwr.781

Halliday, M. A. K. (1978). Language as social semiotic: The social interpretation of language and meaning. Baltimore, MD: University Park Press.

Mayr, E. (1982). The growth of biological thought: Diversity, evolution, and inheritance. Cambridge, MA: Belknap Press.

Miller, C. R. (1984). Genre as social action. Quarterly Journal of Speech, 70(2), 151-167. doi:10.1080/00335638409383686

Miller, C. R. (2012). New genres, now and then. In S. Hulan, M. McArthur \& R. A. Harris (Eds.), Literature, rhetoric and values: Selected proceedings of a conference held at the University of Waterloo, 3-5 June 2011. (pp. 127-149). Newcastle upon Tyne, UK: Cambridge Scholars.

Miller, C. R. (2015). Genre change and evolution. In N. Artemeva \& A. Freedman (Eds.), Genre studies around the globe: Beyond the three traditions (pp. 154-185). Edmonton, AB: Inkshed.

Miller, C. R. (2017). “Where do genres come from?”. In C. R. Miller \& A. R. Kelly (Eds.), Emerging genres in new media environments (pp. 1-34). Cham, Switzerland: Palgrave Macmillan. doi:10.1007/978-3-319-40295-6_1 
Volume 30, 2020

http://journals.sfu.ca/cjsdw

Miller, C. R., \& Shepherd, D. (2004). Blogging as social action: A genre analysis of the weblog. In L. Gurak, S. Antonijevic, L. Johnson, C. Ratliff, \& J. Reymann (Eds.), Into the blogosphere: Rhetoric, community, and culture of weblogs. Minneapolis: University of Minnesota Libraries. Retrieved from http://hdl.handle.net/11299/172818

Miller, C. R., \& Shepherd, D. (2009). Questions for genre theory from the blogosphere. In J. Giltrow \& D. Stein (Eds.), Genres in the Internet: Issues in the theory of genre (pp. 263-290). Amsterdam, The Netherlands: John Benjamins.

Orlikowski, W. J., \& Yates, J. (1994). Genre repertoire: The structuring of communicative practices in organizations. Administrative Science Quarterly, 39(4), 541-574. doi:10.2307/2393771

Schutz, A., \& Luckmann, T. (1973). The structures of the life-world (R. M. Zaner \& H. T. Engelhardt, Jr., Trans.). Evanston, IL: Northwestern University Press.

Spinuzzi, C. (2002). Modeling genre ecologies. Paper presented at the 20th Annual International Conference on Computer Documentation, Toronto, ON. doi:10.1145/584955.584985

Swales, J. M. (2004). Research genres: Explorations and applications. Cambridge, UK: Cambridge University Press. 